\title{
LXI. A general view of the coal mines worked in France, of their different products, and the means of circulating them
}

\section{Lefebvre}

To cite this article: C. Lefebvre (1803) LXI. A general view of the coal mines worked in France, of their different products, and the means of circulating them , Philosophical Magazine Series 1, 15:60, 338-345, DOI: $10.1080 / 14786440308676285$

To link to this article: http://dx.doi.org/10.1080/14786440308676285

曲 Published online: 18 May 2009.

Submit your article to this journal $\pi$

Џll Article views: 2

Q View related articles $\longleftarrow$ 
way; and one man at each end to fteer her, and to be ready at the oppofite end to take the ftern oar when wanted. As, from the conftruction of the boat, the is always in a pofition to be rowed either way, without turning. the boat, when manned, the perfon who fteers her thould be well acquainted with the courfe of the tides, in order to take every poffible advantage: the beft method, if the direction will admit of it, is to head the fea. The fteerfman thould keep his eye fixed upon the wave or breaker, and encourage the rowers to give way as the boat rifes to it; being then aided by the force of the oars, the launches over it with vaft rapidity, without thipping any water. It is neceffary to obferve, that there is often a ftrong reflux of fea, occafioned by the ftranded wrecks, which requires both difpatch and care in the people employed, that the boat be not damaged. When the wreck is reached, if the wind blows to the land, the boat will come in thore without any other effort than fteering.

I would firongly recommend practifing the boat, by which means, with experience. the danger will appear less, from the confidence people will have in her from repeated trials.

LXI. A general View of tbe Coal Mines worked in France, of their different Produds, and the Means of circulating them. By C. Lafenvre, Member of the Council of Mines, of the Pbilomatic Society, \&ic. \&ैc.

[Continued from p. 2;0.]

\section{Department of Ille and Vilaine.}

No coals are dug up in this department. It may receive this fuel by fea in the northern part; and the mines of Montrelais and North, in the department of Loire-Inferieufe, may fupply the fouthern part.

\section{Department of Indre.}

This department is in the fame fituation as the preceding in regard to the want of coal mines. It might be fupplied from the mines in the department of La Creufe, if the river of that name, which is navigable for boats only to Argentan, were rendered navigable higher up.

If the navigation of the Cher were improved, it might alfo fupply with coals the eaftern part of the department of Indre, becaufe the coal mines in the environs of Montlucon would then become an objekt of importance.

Department 


\section{Department of Indre and Loire.}

There are no coal mines in this department; but it receives the products of the mines of various departments by the river Loire, which traverfes it in its longelt direction.

\section{Department of Ifere.}

The fouthern part of this department (22) contains fome coal mines; and particularly in the environs of the communes of La Motte, Pierre-Chatêl, La Mure, Saint-Barthelemi-de-Sechilienne, \&c.

They fupply a mineral combuftible of a moderate quality; but is exceedingly valuable in a country where wood is daily becoming fearcer.

Thefe coal mines are almoft all worked in an irregular manner, without attention to the lives of the work men or to economy.

The annual product of thefe mines may be eftimated at from a million to twelve hundred myriagrammes.

The price at the mines is from 15 to 20 cents per myriagramme; but the difficulty of land-carriage raifes the price at Grenoble to from 60 to 80 cents.

\section{Department of Jura.}

Several indications of coals have been announced in this department; and fome attempts were made 10 work mines, which gave rife to well-founded hopes: but thefe attempts are now abandoned, and no mines are worked in this department.

In the prefent ftate of things, the mines of Blanzy and Saint-Berain, in the department of Saône and Loire, furnin coals to this department by the canal of Charolois and Doubs. The fouthern part is fupplied from the mines of Rives-deGier.

\section{Department of Landes.}

Indications of coal have been announced in the neigh. bourbood of Dax ; but from the nature of the foil it is probable that it is foffil wood. As this department has no coal mines worked, it is fupplied with this fuel by fea, and particularly from the port of Bayonne.

\section{Departmont of Loire and Cber.}

This department (23) has no coal mines. It receives this fuel by the river Loire from the mines of Haute-Loire and Allier. 
Very abundant coal mines are' worked in the cantons of Braffac-Sainte-Florine, Freugères, Vergongheon, and Lempdes, the product of which is confiderable. That of Grofmenil, fituated in the laft-mentioned commune, which had been perforated by a number of fmall pits in fuch a manuer that the ftrata of coal was inundated, is now in the hands of a company, who are cleariug it of water, and making preparations for working it to a greater depth.

There is reafon to think, that this mine alone, when in a productive ftale, will furnifh as much as all the other mines of the country do at prefent. The annual product, however, of the latter is from fifteen to eighteen hundred thouland myriagrammes. Thefe coals are of an excellent quality, The means of their conveyance are the navigation of the Allier and the Loire, the canal of Briare and of the Seine; which gives for their circulation an extent of more than 140 leagues. A large quantity of thefe coals is confumed at Paris. The moan price of them at the pits is from 15 to 20 cents, and when delivered at Paris from 30 to 40 cents per myriagramme.

\section{Department of La Loire.}

The fouth-eaft part of this department (24) contains a great number of coal mines, worked in an extent of more than ten miles in length and five or fix miles in breadth. The principal communes in which thefe mines are fituated are thofe of Rives-de-Gier, Saint-Chamond, Saint-Etienne, Le Chambon, Firnini, Roche-Molicre, \&c.

In confequence of the number and richnefs of the Arala found in thefe cantons, an immenfe quantity of this fuel has been extracted for feveral centuries paft; but in order to obtain it fooner, and with more eafe, a great many pits have been funk, by means of which the coals neareft the furface were dug out. The whole country is perforated with thefe apertures. This irregular method rendered the working of the interior thata much more laborious and expenfive.

The prefent produet of the different mines in this department are thated at thirty millions of myriagrammes annually; and this, in all probability, is below the truth. If the mines were better worked, it is certain that the quantity might be quadrupled.

The quality and price of thefe coals is exceedingly various. Thofe of the firt quality colt at the mine from 10 to 12 cents 
per myriagramme; thofe of mean quality are fold for 7 or 8 cents, and the wortt for 5 .

The medium price of thefe coals tranfported to Lyons is 15 or 18 cents per myriagramme: the price at Marfeilles is 35 cents.

\section{Department of La Laire Inferieure.}

This department (25), as has been feen, may receive coals from the mines fituated towards the upper part of the courfe of the Loire as well as from thofe of Allier. The coals of the mine of Decife, which will be mentioned in fpeaking of the department of La Nievre, are alfo conveyed to different places on the Loire. The coals alfo of the mines of MontreJais, fituated two or three leagues to the north of Varades and Ingrande, are conveyed on the lower part of the Loire. They are embarked in particular at the latter place to be tranfported to the communes on the banks of that river defcending to Nantes, where the confumption is confiderable.

The coals annually extrasted from the fe mines may be fafely eftimated at a million of myriagrammes. They are of a good quality. The mean price on the fpot is 5 cents per myriagramme; when fent to Nantes, the fame quantity colts 25 cents.

In this department there are allo peat-moffes, the product of which is abundant, and of great ntility to the inhabitants. The moft confiderable are found in the marfnes of Montoirc, to the north of Nantes. More than eight thoufand individuals are employed in digging peat from thefe moffes.

\section{Dipartment of Lire and Cber.}

There are no mines worked in this department. It receives coals by the Loire, which traveries it; and might confume thofe alfo brought by the Cher from the mines lituated in the environs of Commentry and Montluçon, in the department of Allier, if the navigation of the Cher were improved.

\section{Deparment of Loiret.}

There are no coal mines worked in this department; but it is abundantly provided with coals by the navigation of the Seine.

\section{Department of Lot.}

Abundant coal mines exift in the environs of Figeac, towards the eaft extremity of this department. They are badly worked by the proprietors of the ground; but thev are fufceptible of improvement, if means of confumption were opened for their products. 


\section{Department of Lot and Garonne.}

No coal mines are worked in this department. Thofe extracted from the mines of Carmeaux, in the department of Tarn, are brought to it on the Garonne; and it receives by the Lot thofe of the department of that name, which would be fupplied much cheaper if the Lot were rendered navigable towards Figeac and the department of Aveyron.

\section{Department of La Lozere.}

The difcovery of fome ftrata of coal in this country would be of great utility. Wood daily becomes fcarcer; and the communication with the coal countries in the neighbouring departments is difficult and expenfive.

Several indications of coal bave been announced; particularly towards Canourgue, towards Mende, and in the neighbourbood of Meyrney. Some fpecimens fent to the Council of Mines announce only foffil wood.

$$
\text { Department of Lys. }
$$

This department has no coal mines worked. It receives thofe of the departments of the North and of Jemappes.

\section{Department of La Manche.}

There are feveral indications of coal in this department; and particularly in the Foreft of Briquebec, near Valonges; in the commune of Pleffis, near Fretot; in that of Monn, and hat of Semilly, in the diffrict of Saint-Lô.

Strata of coal have been found in the commune of Pleffi; but hitherto they are fo intermixed with frata of fchift, that if worked they would not pay the expenfes.

\section{Department of La Marne.}

This department, as far as is yet known, has no coal mines. Collections of foffil wood, and of peat exceedingly prritous, are frequently found under flrata of marly earth. Thefe fubfances have often been announced as coal, but they do not poffefs the qualities of that fuel. They kindle nowly, and become totally incandefcent; but they give very jittle flane, and for the moft part none at all. 'This fubfance is called by the inhabitants earth coal.

The Valley of La Vente furnifhes abundance of peat of an excellent quality. This river, which takes its fource on the eaft of Chalons, paffes Rheims and Braine, and difcharges ititfelf into the Aifne above Soiffons, traverfing an extent of eighteen leagues. It every where runs over a bed of peat, 
and may afford great refources to the neighbouring communes if that fubltance were properly dug up.

\section{Department of La Haute Marne.}

There are no coal mines worked in this department. Several indications of coal have been announced, but hitherto the fpecimens have turned out to be bituminous foflil wood. This department is at a diftance from coal countries, and has on eafy communication with them; but it is abundant in wood.

\section{Department of La Mayonne.}

This department is fupplied with coals by the Loire. Boats can go up the Mayenne as far as Laval; and the Sarthe as far as Mons.

\section{Department of Mayenne and Loire.}

There are feveral fmall coal pils worked in the canton (26) of Saint-Aubin-de-Luigné, in the territories of Chaudefond, Montjean, and feveral other places adjacent. They are worked very irregularly, and the product of them is not known.

The mine of Saint-George's-Châteloifon, fituated between Vihiers and Doué, to the eaft of the latter commune, is more important and worked in a more regular manner. The produet amounts to about 300,000 myriagrammes per annum; but it might be rendered more confiderable.

\section{Department of La Meurtbe.}

A difcovery of coal has been announced in the neighbourhood of Nancy; but the fpecimens fent were only bituminous foffil wood. At prefent this department has no coal mines actually worked.

\section{Department of the Meufe.}

No coal mines are worked in this department (27). It can receive coals from La Saare by the Mofelle, and the canal which communicates with the Meufe between Toul and Pagny: and the coals of the department of Ourthe may be conveyed on the Meufe to its northern part.

$$
\text { Deprartment of La Meufe Inferieure. }
$$

This department poffeffes very important coal mines in the neighbourhood of Rolduc. The annual product of them amounis to more than 13,500,000 myriagrammes; and they are far from being properly worked.

The coals are of different qualities; fome of them are very good. Their mean price at the mine varies from 5 to 14 cents 
per myriagramme. There is alfo abundance of peat in the cantons of Heythnyfen and De Weert.

\section{Department of Mont-Blane.}

There are feveral coal mines in this country (28). Some are worked in the terrirory of the communes of Entrevernes near Annecy, Montmin, Novalaife, Scrvolex, and PetitBernard. Indications of coal have been announced alfo in the canton of Moutiers, Crufeilles, Valloires, and Cognin. The annual product of the cral mines worked in this department may be efimated at 120,000 myriagranmes per annum. 'Thefe mines are fulceptible of improvement, but there is no confumption. The price of the coals at the mine is 5 cents per myriagramme.

\section{Dipartment of Moni-Tonnere.}

There are more than thirty coal mines known in this department (29). Several of them bave been abandoned in comfequence of the war. The cantons molt abundant are thole of Lautereck, Wolftein, and Obermofchel.

The product of thefe mines may be eftimated at about 425,000 myriagrammes; but if the confumption required, it could be increaled. The quality of the coal varies. There is very little of it good; but it is generally ufed for heating Roves. The price at the mines is 8 cents per myriagramme.

Thefe coals are confumed mercly by the wants of the country. A confiderable quantity of them is employed for burnins lime, either for building or for manure. They are employed alio in the fuing of mercury, of which there is very important mines in this department; and for the purpofes of evaporation in the filt-works of Kreutznach.

\section{Dipartment of Morbiban.}

The Morbilan has no coals. It receives thofe which are dug up on the banks of the Loire, or of the rivers united with it.

$$
\text { Department of La Mofelle. }
$$

Some coal mines are worked in this department (30) in the environs of the communes of Oltenbach and in the canton of Petelange. The anmual product of them may be eftimatid at 100 , co myri:grammes at leatt. The coul is of a very good quality. It coits at the mine 9 cents per nyriagranume.

$$
\text { Department of the Two Nethes. }
$$

This department has no coal mines; but it is fupplied 
with abundance of coal from the mines in the departments of Jemppes and of the North, by the canal of Bruffels and by the scheidt.

\section{Department of the Nortb.}

Very important coal mines are worked at Anzin near Valenciennes, at Frefnes, Raifmes, and Vieux-Condé. There is a very confiderable one alfo in the commune of Aniche.

The different mines worked in this de rarment funifh at the leaft 30,000,000 of myriagrammes. They are of varions quahties. Some of them are very good fur forging iron; others are preferable for ftores; and fome of an intirior cinality are proper for burning line. The price at the mines differs arcording to the quality. The nucan price of good coal is from 12 to 15 cents per myriagramme. Whien delivered at the ports of Oftend, Dunkirk, and Calais, it colts from 25 to 28 , and at Havre from 52 to 55 .

The means of coufumplicu for thefe crals, and particularly for thofe-near Conde and Sant-Amand, are very extenfive towards the north, on account of the navication of the Scheldt, and of the numerous canals which communicate with that river. So that the products of thefe nines might be convered at very litile expenfe as far as Ghent, Bruges, Oftend, Termonde, and Antwerp. They might alfo be circulated in Holland, and be experted by the ports of Oftend and Dunkirk, fo as to become as important an object of mapitime commerce as the Englith coals.

\section{Departmest of La Niture.}

Coal mines are worked in the canton of Decife (32), and are very proluctive. The anmual product is efimated at I, 000 , oo of muriagrammes, but nay be much increafed. The quality of thefe cods is in general fuch that they mut be firecdity employed atter they are dug up, as they lofe confrderdbly by long cxpofore to the air. The price at the mine is from 8 to 10 ceuts per myriagramme; and delivered at Paris from 1'to I3. They are conveyed on the Loire, the canal of Briare, the Seine, \&c.

[To be continued.] 